\title{
Spatial Attractions: The Literary Aesthetics of Female Erotic Experience in the Colony
}

\author{
Anna Ziajka Stanton
}

\begin{abstract}
This article examines the aesthetics of representing female sexuality within colonial narratives of the West-East encounter. I consider two literary works whose female characters challenge the gendered metaphors of empire that predominated in a tradition of colonial literature and its postcolonial rewriting: the short story "La femme adultere" by the French-Algerian writer Albert Camus, and the novel Wāhat al-ghurūb by Egyptian writer Bahà 'Tähir. In each text, the standard heterosexual troping of imperial conquest as a male activity directed at or against a feminized other is inverted to place a European woman's sexually aroused body at the center of the drama of colonial contact. Reading these two texts against the grain of the aesthetic formulas that they employ to contemplate the political stakes of cross-cultural intimacies in a colonial setting, I argue that the phenomenological immediacy of how the female protagonist in each is shown to experience the eroticism of colonial space introduces a break in these formulas. The loss of narrative plausibility in each text that follows from these erotic interludes, I propose, ultimately testifies to the irreducibility of the body to either enforcing or disputing the epistemologies of the colonial project.
\end{abstract}

Keywords: colonial literature, aesthetics, the postcolonial novel, women in fiction, female sexuality, affect

\section{Gendering Empire}

She "would have liked to take up less space," we are told of the Algerian-born Frenchwoman Janine, who accompanies her husband reluctantly on an expedition to sell fabrics in Algeria's arid south in Albert Camus's (1913-1960) short story "La femme adultère" ("The Adulterous Wife"), from his 1957 collection L'exil et le royaume. ${ }^{1}$ Described as someone who stands "heavily" ("pesante") and moves by "dragging her

Anna Ziajka Stanton is Caroline D. Eckhardt Early Career Professor of Comparative Literature and Assistant Professor of Comparative Literature at The Pennsylvania State University. She is a scholar of Arabic literature and culture, world literature, and translation theory, as well as an active translator of Arabic texts in multiple genres. (Email: azstanton@psu.edu)

1 Albert Camus, "La femme adultère," L'exil et le royaume (Paris: Gallimard, 1957), 24. Carol Cosman's translation of the complete collection was published by Vintage International in 2007. All translations from the story that appear in this article, however, are my own. 
body" ("trainant son corps") behind her, Janine is shown furthermore to suffer from a litany of physical ailments during the course of her journey: breathlessness, fatigue, indigestion, insomnia, fever, and extreme cold. ${ }^{2}$ In comparison to her husband Marcel's body, which is "subsumed by and made subordinate to his mercantile activities" throughout the story-effectively disappearing from view, as it functions merely to extend the capitalist principles of the French colonial state into a corporeal register-Janine's body is an overwhelming yet underdetermined presence in Camus's text. ${ }^{3}$ What is this prodigiously embodied female character, who is notably the only female protagonist in any of Camus's literary works, doing in this story, and more specifically, how can Janine's embodied phenomenal experiences of colonial space be understood in the context of the story's obviously colonialist, Orientalist, and masculinist mimetic tendencies?

I am not the first critic to pose such questions about Janine, who fits uneasily among the overall cast of characters in Camus's oeuvre. Vicki Mistacco has argued for seeing Janine's body as symbolizing a "metaphysical, political, and economic crisis" in the systems of French imperialism in North Africa that Camus's text attempts first to reveal, and later to sublimate within "the hegemony of white male bourgeois representations" of a female figure rendered passive under the dictates of Camus's own authorship. In this regard, what Janine's body signals to Mistacco, insofar as it proves resistant to Camus's representational strategies, is a "potential [for] subversion from the margins": it is a body whose femininity makes it always already a challenge to the misogynistic tendencies of his literary discourse. ${ }^{4}$ In Brian Fitch's reading of "La femme adultère," Janine's body can be discerned as a literary device for corporealizing the existential malaise that haunts many of the male protagonists of Camus's other works. Whereas the body provides relief from anxiety and ennui for "a Meursault, a Tarrou or a Rieux swimming in the ocean," for Janine, by contrast, "it clearly does not feel good to be alive and to experience the heightening of her consciousness of her own bodily existence." ${ }^{5}$ Far from serving as a source of probable resistance to the status quo, Janine's body according to Fitch instead relegates her to suffering doubly (physically as well as psychically) what Camus's male characters endure only as a psychological burden.

Janine's embodiment of White European femaleness within the phenomenological environment of colonial space also positions her ambivalently vis-à-vis prior predominant European literary imaginings of the role of the female body in the West-East colonial encounter. Discussing the development of French Orientalist literature during the nineteenth century, Lisa Lowe notes an enduring trope whereby "representations of the Orient as cultural opposite of the Occident are eroticized and feminized" within a gendered "spatial logic" that casts the non-European female body as a narrative stand-in for the territorial object of European colonial and imperial intentions. ${ }^{6}$ Along similar lines, Mohja Kahf describes a pervasive romantic conflation of the figure of the Oriental

2 Camus, "La femme adultère," 22, 33.

3 See Vicki Mistacco, "Nomadic Meanings: The Woman Effect in 'La Femme adultère," Albert Camus' L'Exil et le royaume: The Third Decade, ed. Anthony Rizzuto (Toronto: Les Éditions Paratexte, 1988), 75. 4 Mistacco, "Nomadic Meanings," 72, 75.

5 Brian T. Fitch, "La Femme adultère': A Microcosm of Camus' Solipsistic Universe," Albert Camus' L'Exil et le royaume: The Third Decade, ed. Anthony Rizzuto (Toronto: Les Éditions Paratexte, 1988), 119. Meursault, Tarrou, and Rieux are characters in Camus's novels L'étranger (1942) and La peste (1947).

6 Lisa Lowe, "The Orient as Woman in Flaubert's 'Salammbô' and 'Voyage en Orient,"” Comparative Literature Studies 23.1 (1986): 44. 
woman with Oriental space in a range of colonial-era Western literary works, such that the "recurrent drama of incipient colonization" comes to be staged aesthetically in these texts as "that of a heroic male conquest of a feminized Oriental land." and Gillian Rose put it, "Imperialist literature often incorporated sexual imagery to create and sustain the heroic stature of male colonizers who conquered and penetrated dangerous, unknown continents." Insofar as the "construction of a 'sexual space' paralleled the construction of space to be colonized," they propose, "the desire for colonial control was often expressed in terms of sexual control." 8

Janine's character in "La femme adultère" inverts these typical literary formulas. Instead of a male European protagonist whose desire for territorial acquisition is displaced figuratively into a desire to possess sexually the body of a non-European woman, Camus's story envisages a European woman whose sensations of illness and discomfort are ultimately eclipsed by the sexual pleasure that she derives from physical contact with the wildness of colonial space itself. The phenomenological account that the story constructs of Janine's lived experiences in the Algerian desert thus problematizes the bipartite troping of woman-as-land and land-as-other that undergirds the metaphors of sexual intercourse most frequently employed in colonial literature to describe Westerners' encounters with the material realities of the colony. Building on Ato Quayson's insights about the ways that disabled bodies function as "excessive" to the aesthetic conventions of a normative European literary tradition of writing the body by intervening to produce "a series of crises in the protocols of representation" upon which such literature is premised, I propose that the disruptive significance of Janine's body in relation to the West-East encounter narrative that Camus's story invokes must be understood in aesthetic and formalistic terms. ${ }^{9}$

How Janine's body counters the prevailing colonial literary topos that figures Western experiences of colonial space as essentially male and essentially eroticized within a framework of heterosexual desire manifests as a rupture in the believability of this particular story. Taking my reading of Camus's story as a model, in the second half of this article I examine how the aesthetic conventions of colonial literary writing about the female body operate in a literary text of a very different provenance: Egyptian writer Bahā' Tāhir's (b. 1935) International Prize for Arabic Fiction-winning novel Wāhat al-ghurūb (Sunset Oasis), published in 2007. ${ }^{10}$ Like "La femme adultère," Wähat al-ghurūb, which is set in late-nineteenth-century British-occupied Egypt, centers on a European woman who discovers in the physicality of colonial land a heretofore unexpected source of erotic pleasure. Just as for Janine it is a journey out of the unnamed city where she and Marcel live and into the Algerian desert that furnishes an opportunity for this discovery, Kāthrīn (henceforth, Catherine), who is Irish, is traveling with her

7 Mohja Kahf, Western Representations of the Muslim Woman: From Termagant to Odalisque (Austin: University of Texas Press, 1999), 8.

8 Alison Blunt and Gillian Rose, "Introduction: Women's Colonial and Postcolonial Geographies," in Writing Women and Space: Colonial and Postcolonial Geographies, eds. Alison Blunt and Gillian Rose (New York: The Guilford Press, 1994), 10.

9 Ato Quayson, Aesthetic Nervousness: Disability and the Crisis of Representation (New York: Columbia University Press, 2007), 14.

10 An English translation by Humphrey Davies was published by Sceptre under the title Sunset Oasis in 2009 . 
Egyptian husband, Mahmūd, from Cairo to the Siwa oasis in Egypt's Western Desert when her phenomenal experiences of colonial space begin to take on the affective resonances of a sexual event.

These two texts have divergent genealogies as works of literature whose plots unfold in colonial North Africa: the first is a short story by a Francophone Algerian Pied-Noir author whose position on Algerian independence from French colonial sovereignty was at best ambivalent, ${ }^{11}$ whereas the second is a work of historical fiction by one of the most celebrated members of the so-called "1960s generation" of socially committed realist Egyptian writers who emerged under the aegis of postcolonial Nasserist nationalism. ${ }^{12}$ By highlighting the similarities between how these texts recast a tropic structure familiar to colonial literary narratives - by portraying the female European body, rather than its male counterpart, as the site where the erotic possibilities of the West-East encounter are realized-I aim to show that the representation of the sexually aroused female body poses a challenge to both the colonial aesthetics of metaphorizing imperialist intention as sexual desire and to the postcolonial rewriting of this aesthetic approach. Again with reference to Quayson's arguments about the literary representation of certain kinds of marginal bodies, I propose that what he describes as instances of "short-circuiting" that occur in literary texts that attempt to aestheticize such bodies within a normative discursive imaginary can be identified as well in both of the works that I examine, despite their ostensibly opposite stances on the politics and ethics of European colonialism in North Africa. ${ }^{13}$ As both Camus's short story and Tāhir's novel reduce the corporeal complexity of female sexual desire to transform it into a vehicle for reflecting imaginatively on the territorial and spatial extension of imperial power, the plausibility of each literary narrative cedes to the aesthetic excesses of the bodies of these two female characters, who experience colonial space as an affective epiphany outside the bounds of what can be represented within the conventions of colonial literary writing.

\section{Implausible Realities: Albert Camus's "La femme adultère"}

Janine's heavy female body marks her from the opening moments of Camus's story as distinctive within a diegetic reality from which other female characters are wholly absent. The sole woman on the bus that she and Marcel take south, she becomes an object of interest for a French legionnaire who is riding the bus with them, and whose penetrating stare, we are told, makes Janine "blush" and reminds her that she is "not so fat, but rather large and full, fleshy, and still desirable." ${ }^{4}$ From the outset, then, if we have not already gleaned an idea of what will happen to Janine from the story's title, we can anticipate that whereas Marcel's plot arc is governed by the logic of commercial enterprise that has driven him to seek financial profits in the Algerian desert, Janine's

11 See, for example, Emily Apter, "Out of Character: Camus's French Algerian Subjects," MLN 112.4 (1997): 499-516.

12 See Richard Jacquemond, Conscience of the Nation: Writers, State, and Society in Modern Egypt, trans. David Tresilian (Cairo: American University in Cairo Press, 2008), 286. As Jacquemond notes, many of the sixties generation writers later broke with the state under President Gamal Abdel Nasser's successor Anwar Sadat to produce fiction critical of the postcolonial regime's authoritarian tendencies.

13 Quayson, Aesthetic Nervousness, 15.

14 Camus, "La femme adultère," 14-15. 
will follow a more intimate trajectory. Her marriage to Marcel has been childless and, it is implied, sexually unfulfilling. What Janine stands narratively to gain from this journey must be the realization of her body's still-latent sexual potential in a space outside the confines of her domestic urban milieu.

Once they disembark in an oasis town where Marcel hopes to sell his textiles to the native population of Algerians, it is by contrast the lack of interest shown to Janine by a "slender, vigorous" Algerian man - who rushes past her in the street apparently without noticing that she is there-that motivates her to take action for the first time in the story. ${ }^{15}$ (Previously, she has trailed along behind Marcel in near-total silence, as they lunch extravagantly on pork and wine at their hotel and he haggles tetchily with the local merchants.) Janine reminds Marcel that the fort standing on the edge of the town is supposed to offer an impressive view of the surrounding desert; she would like to see it. They climb the stairs to the fort's high parapets, and from there Janine beholds "the overlapping blue and white terraces of the Arab village, stained as though with blood by the dark red spots of peppers drying in the sun," smells "the pungent aroma of coffee being roasted," and hears "laughing voices and incomprehensible footfalls." In the further distance are palm trees, the black tents of shepherds, and "a troupe of immobile dromedaries ... forming against the gray ground the dark signs of a strange writing whose meaning must still be deciphered."16

In Mary Louise Pratt's reading of this passage, Janine's observations betray an imperial gaze that fails to grasp all that it surveys. Despite her commanding perspective on it, the colonial landscape remains in its totality incomprehensible and indecipherable, beyond the limits of her ability to ascribe meaning to the inscriptions that it bears upon its variegated surfaces. For Pratt, that Janine's knowledge of the colonial landscape is shown to be incomplete distinguishes her as a "Euro-African" from the "European seeingman" who features in classic colonial scenes of territorial surveillance, revealing the hybrid subjectivity of a White Frenchwoman born in Algeria who can never entirely nor convincingly (neither to herself, nor to us as readers) play the part of the colonizer. ${ }^{17}$

If the description of what Janine sees from the fort deviates from the standard script of scopic mastery that Pratt identifies as the basis for so many historic European accounts of colonial exploration and discovery, both literary and autobiographical, then I propose that by exposing the insufficiency of Janine's sight as a tool of knowledge, this episode simultaneously allows alternative means of perceiving colonial space to come to the fore. Bill Ashcroft argues that in their privileging of an exclusively ocularcentric perspective on colonial landscapes, European conceptualizations of "place in the colonized world" suppressed "other ways of knowing, whether through other senses or other intuitive or imaginary forms of cognition." 18 Janine's encounter with the Algerian desert here makes it knowable to her only in what is inevitably a partial fashion, via her sensual perceptions of it. She smells, tastes, and hears colonial space; "pushing her whole body against the parapet," she extends herself toward this space, and in so doing, she becomes

15 Camus, "La femme adultère," 27.

16 Camus, "La femme adultère," 30-31.

17 Mary Louise Pratt, Imperial Eyes: Travel Writing and Transculturation, 2nd ed. (New York: Routledge, 2008), 219.

18 Bill Ashcroft, Post-Colonial Transformation (New York: Routledge, 2001), 127. 
aware of it as a "vast territory that her view had discovered" and "yet would never be hers." 19 Sight is invoked and then discarded in Camus's story as an adequate apparatus for positioning the European self to possess the material realities of the colony. Algeria signifies instead here as a sensorium of phenomenal experiences available to a European body that apprehends colonial space thickly, in the terms of phenomenologist Maurice Merleau-Ponty: as a sensible world rendered perceptible via the "weighty mass that is our body." 20

When Janine returns alone to the fort later that night while Marcel is sleeping, her sensual experiences of colonial space are figured in explicitly erotic terms:

Before her, the stars were falling, one by one, then extinguishing themselves upon the stones of the desert, and each time Janine opened herself a little more to the night.... At the same time, she seemed to be recovering her roots, the sap rising anew in her body that was no longer trembling. Pressing her whole belly against the parapet, leaning toward the whirling sky, she waited only for her still-pounding heart in turn to grow calm, and for the silence to form in her. The final stars in the constellations dropped in clusters a little lower down on the desert horizon, and stopped there motionless. Then, with an unbearable sweetness, the water of the night began to fill Janine, submerging the cold, and rose little by little to the obscure center of her being, and overflowed in erratic gushes from her moaning mouth. A moment later, the entire sky stretched out above her as she lay prone upon the cold earth. ${ }^{21}$

For Mistacco, this episode is a symbolic expression of Janine's monstrous jouissance that finally overwhelms her husband's phallocentric world order; ${ }^{22}$ for Fitch, it demonstrates Janine's ultimate potential for liberation through physical pleasure from what ails her body. ${ }^{23}$ Pratt, for her part, understands Janine's erotic communion with colonial space as "a kind of cultural adultery" that enacts a "momentary permeation of the colonialist boundaries between Euro-African and Africa," as the "fluid boundaries of female subjectivity provide the means for imagining what a decolonization of self might mean." 24

Following Pratt but putting emphasis on the fluidity of Janine's corporeal rather than subjective boundaries that this scene reveals, I propose furthermore that her sexual encounter with Algerian space constitutes an event of systemic rupture in the representational logic of Camus's colonial discourse, by introducing an affectively porous female body into the narrative. Janine's body here acts not as the individual body posited by "Western" philosophy as "an energetically self-contained or bound entity, whose affects are his or hers alone," but as a body whose potential hinges on, and is actualized only by means of, its interactions with others. ${ }^{25}$ This relational body is radically at odds with the underlying epistemologies of the colonial project that Janine and Marcel represent, and upon which Camus's narrative depends aesthetically for its portrayal of

19 Camus, "La femme adultère," 31-32.

20 Maurice Merleau-Ponty, Phenomenology of Perception, trans. Donald A. Landes (New York: Routledge, 2014), 52.

21 Camus, "La femme adultère," 40-41.

22 Mistacco, "Nomadic Meanings," 79.

23 Fitch, "La Femme adultère," 119.

24 Pratt, Imperial Eyes, 220.

25 See Teresa Brennan, The Transmission of Affect (Ithaca, NY: Cornell University Press, 2004 ), 24. 
a West-East encounter figured in the journey of a Pied-Noir couple into the Algerian hinterlands, where "nothing" is as they "had imagined" it would be, and the "Arabs" that they meet along their route evince alien ways of being and living wholly opaque and inaccessible to their European sensibilities. ${ }^{26}$

That Janine's body is moreover sexed as female compounds the problem that this scene creates for the mimetic apparatus of Camus's text. If Janine's first visit to the fort depicted the imperialist knowledge-mode of seeing-as-mastering ceding to the phenomenological experience of relating to the colony through the senses, then the account of her second visit marshals a sensorial register of descriptive language to portray the sense-data gathered by her body translating into sexual climax. Departing from the realist literary mode in which the story up to this moment has been told-a realism that frames its Orientalizing portrait of Algeria's native population within a deceptive guise of verisimilitude-Camus's text moves into a mythical and metaphorical register, where Janine's orgasmic reaction to being at the fort evokes a welter of symbolic associations far removed from the realities of how a woman in her situation might actually be led to feel sexual pleasure. Janine's scene at the fort is presented as an enigmatic interlude that rehashes the well-established "fantasy of the inscrutable that man attributes to women," and particularly to women's sexualized bodies, in Elizabeth Grosz's terms. ${ }^{27}$

Rather than representing female sexual experience, in other words, Camus's text deploys it mythopoetically as a literary device to indicate the ineffability of the other that Janine comes at this moment to personify. By the end of "La femme adultère," the other against whom the text's normative ontology of the European man in the colony was initially established has become no longer only a cultural other (the indigenous Algerians) but also a gendered other (Janine herself). The binary of European subject/self versus non-European other that initially lent dramatic purpose to Camus's story, while affiliating it genealogically with a lineage of colonial literary representations of WestEast encounters occurring in colonial settings, no longer holds when the narrative is compelled to incorporate a female character whose experiences "assert the priority of the body over subjectivity." 28

The entire plot of "La femme adultère" has been a slow buildup toward Janine's apex of physical feeling. Janine's body is, to borrow Quayson's formulation, a "constitutive point" for "the process of emplotment" that the story sets in motion from its opening sentences. ${ }^{29}$ Janine's unrealistic erotic encounter with colonial space thus produces a break in the text's narrative coherence. After leaving the fort, Janine returns to the hotel, weeping, and as Marcel looks on "uncomprehendingly," she does not explain her tears but only repeats, "It's nothing" ("Ce n'est rien"). ${ }^{30}$ The "excessiveness" of Janine's weeping parallels the excesses of her female body to Camus's own act of writing. ${ }^{31}$ With this literally meaningless statement from its protagonist, the story ends, closing on itself

26 Camus, "La femme adultère," 17.

27 Elizabeth Grosz, Volatile Bodies: Toward a Corporeal Feminism (Bloomington and Indianapolis: Indiana University Press, 1994), 191.

28 Grosz, Volatile Bodies, 194.

29 Quayson, Aesthetic Nervousness, 21.

30 Camus, "La femme adultère," 41.

31 See Grosz, Volatile Bodies, 196. 
by negating the capacity of signifying language to account for Janine's embodied experiences.

Other critics have posited various understandings of what happens to Janine at the fort, interpreting her sexual climax through a Freudian lens as indicating that she has finally overcome her longstanding libidinal frustrations, ${ }^{32}$ as an allegorical commentary on biblical original $\sin ,{ }^{33}$ and as the culmination of an extended dream sequence inspired by her journey into the desert. ${ }^{34}$ Mistacco, for her part, casts Janine's insistence on saying "nothing" to Marcel after she returns to the hotel as an act of deliberate feminine resistance to male authority. ${ }^{35} \mathrm{I}$ am not entirely convinced by these readings, none of which adequately attends to the tension between how Janine's body functions within the representational formulas internal to Camus's text and how the text itself is situated vis-à-vis the overarching mimetic tropes of colonial literary writing. That the sensory and sensual account of the female body in colonial space that the story offers is ultimately one that emerges in spite of, and as a disruption to, the text's own plausibility as an ostensibly realistic portrait of colonial Algeria would seem to undermine any reading of "La femme adultère" as an explicitly dissident fiction in either feminist or decolonial terms (per Pratt). Insofar as the erotic affects triggered by Janine's phenomenological experiences of colonial space have the power to destabilize imperial epistemologies, this revelation occurs accidentally, manifested in the aesthetic incoherence of Camus's literary portrait of French Algeria as a backdrop for a basically Eurocentric imagining of the recurring colonial drama of self and other.

\section{Characters in Crisis: Bahā' Țāhir's Wāhat al-ghurūb}

Bahā' Tāhir's novel Wăhat al-ghurūb presents a different view on a similar set of themes. When the narrative begins, Catherine has been recently liberated from an unhappy marriage in Ireland by her husband's untimely death. In hopes of starting anew, she travels to Egypt, where she falls for Mahmūd because "his stern face with its wide black eyes and harmonious features" reminds her of the visage of a pharaoh who has "stepped off the walls of a temple." ${ }^{36}$ After they are married, Mahmūd-who holds a bureaucratic position with the colonial British government in Cairo-is assigned to travel to the Siwa oasis near the Libyan border in Egypt's Western Desert to collect overdue taxes from the Amazigh tribes who live there. Catherine begs him to take her along, captivated by rumors that one of the oasis's numerous ruined temples may conceal the long-lost tomb of the Macedonian emperor Alexander the Great. ${ }^{37}$

32 See Simon P. Sibelman, “The Anguish and the Ecstasy: Camus's Use of Phallic Symbols in 'La femme adultère," Dalhousie French Studies 45 (1998): 41-54.

33 See Rob Roy McGregor, "Camus's 'La Femme adultère': A Metaphor of the Fall from the Absurd," The French Review 67.3 (1994): 478-85.

34 See Valerie Waters, “Camus's 'La Femme Adultère': Janine's Dream," Romance Studies 9.2 (1991): $65-73$.

35 Mistacco, "Nomadic Meanings," 81.

36 Bahā' Tāhhir, Wāhat al-ghurūb (Cairo: Dār al-Shurūq, 2007), 20. All translations from the novel are my own.

37 Siwa was annexed for the Egyptian state by Muhammad Ali Pasha in 1819. Known among Egyptians today mainly as a tourist destination, during the first century of state rule Siwa acquired a reputation first for the recalcitrance of its native Amazigh (Berber) inhabitants, who refused to pay tribute to the Cairene 
Following on this opening, the first section of the novel details Catherine and Mahmūd's journey across the desert to Siwa, and the second section describes the various events that occur once they reach their destination.

Catherine's enthusiasm for ancient Egypt is portrayed at the outset of the novel as an epistemological impediment to her ability to value contemporary Egyptians or Egyptian culture beyond the extent to which these seem to grant her access to an idealized Egyptian history across "the vertical depth of the past," in Timothy Mitchell's formulation. ${ }^{38}$ Mahmūd is no more than a living avatar of the country's pharaonic era for her, whereas Siwa matters only for its Ptolemaic heritage. As reviewers of both the Arabic novel and its English translation have noted, Catherine appears as "a symbol of the contemptuous Orientalist, critical of everything ... [who] looks down on the Egyptians in the way of many Westerners." ${ }^{\text {" }}$ At no point in the early chapters of the novel does she evince any concern for Egypt's current political situation, whose stakes, however, are only too well known to her husband, a former revolutionary before he became a flunky in the colonial administration, who had been injured while fighting alongside the Egyptian nationalist Ahmad 'Urābī in Alexandria. ${ }^{40}$

The juxtaposition of these two characters, one European and one Egyptian, at the center of Țāhir's novel has been interpreted by critics primarily with respect to what their dynamic interactions reveal about Mahmūd as a "colonial subject" whose psychological "predicament" is his "entrapment in the colonizer's preconceived image and prescribed role," in Mary Youssef s phrasing. ${ }^{41}$ For Karam AbuSehly, Mahmūd is a man beset by a "crisis" of temporality that Catherine's total immersion in the past accentuates. Whereas Catherine can give herself over fully to Egyptian history and thus avoid dealing with the problems of the country's colonial present, Mahmūd "is torn apart by all modalities of time," as he is driven ceaselessly and unproductively to mine his country's cultural heritage for a means of achieving its postcolonial future. ${ }^{42}$

government, and later as a place of anthropological interest for Egyptian scientists and scholars. See Omnia El Shakry, The Great Social Laboratory: Subjects of Knowledge in Colonial and Postcolonial Egypt (Stanford, CA: Stanford University Press, 2007), 44-45. Alexander the Great is reputed to have visited Siwa in the fourth century BCE after founding the city of Alexandria on Egypt's Mediterranean coast.

38 Timothy Mitchell, Colonising Egypt (Berkeley and Los Angeles: University of California Press, 1991), 140.

39 This description comes from an unsigned Arabic review of the novel in the Dubai-based newspaper alBayān. See “Wäḥat al-ghurūb," al-Bayān, November 15, 2008 (https://www.albayan.ae/paths/books/200811-15-1.692458); my translation. Reviewers of the novel's English translation have offered similar assessments of Catherine's character. See Rachel Aspden, review of Sunset Oasis by Bahaa Taher, trans. Humphrey Davies, The Guardian, October 31, 2009 (https:/www.theguardian.com/books/2009/nov/01/sunset-oasisbahaa-taher); and Sameer Rahim, review of Sunset Oasis by Bahaa Taher, trans. Humphrey Davies, The Telegraph, October 27, 2009 (https://www.telegraph.co.uk/culture/books/bookreviews/6408498/SunsetOasis-by-Bahaa-Taher-review.html).

40 Led by Colonel Aḥmad 'Urābī, a group of Egyptian nationalists attempted to oust the British military from Egypt during the period of 1879-1882. The failure of the so-called 'Urabi revolt led to the total occupation of Egypt by Britain after 1882.

41 Mary Youssef, "The Aesthetics of Difference: History and Representations of Otherness in al-Nubi and Wahat al-ghurub,” Alif: Journal of Comparative Poetics 35 (2015): 91.

42 Karam AbuSehly, "The Dialectic of Nonsimultaneity in Bahaa Taher's Sunset Oasis," Arab Studies Quarterly 41.2 (2019): 137. 
My reading of TTāhir's novel pivots from focusing on Maḥmūd's psyche-in-crisis to examine instead Catherine's evolution from an Orientalist for whom Egypt's importance lies entirely in its past into someone capable of experiencing Egyptian space phenomenologically and affectively. Building on my reading of Camus's story, I interpret this change in her character vis-à-vis the formal crisis that it induces in the literary text's own representational frameworks. When the imperial knowledge-modes with which Catherine's character is affiliated diegetically at the start of the narrative prove unable to accommodate her embodied responses to Egypt's material realities, this triggers a concomitant collapse in the conceptual scaffolding that furnishes the basis for this postcolonial novel's extradiegetic critique of colonial history. The shift from the total knowledge of the colony provided by the all-seeing imperial gaze to the contingently relational and experiential knowledge provided by the female body that is elaborated in Camus's story plays out in Tâhir's text as well, but in the latter, what is undermined and disrupted in this shift is not the mimetic and narrative structures of colonial literary discourse about European encounters with the colonial other, but the postcolonial rewriting of this discourse.

A basic feature of postcolonial literature, according to classic definitions of the genre, is that it derives its representational protocols from the colonial literature against which it "writes back," in Bill Ashcroft, Gareth Griffiths, and Helen Tiffin's phrasing. ${ }^{43}$ For Barbara Harlow, the relationship of a postcolonial literary text to its colonial antecedents is most often governed by "a formula whereby one person will write ... and another will retaliate by writing along the same lines, but reversing the meaning." ${ }^{44}$ As noted by Hoda Elsadda, late twentieth- and twenty-first-century Egyptian postcolonial fiction has tended to move beyond a straightforward "paradigm of sameness and difference" and the corollary "Manichean aesthetic" that predominated in an earlier generation of colonial-era Egyptian literary representations of "the encounter with the West." ${ }^{45}$ TTăhir's novel exemplifies this trend insofar as it does not simply reverse the moral valences of the colonial encounter-by showing the West in a negative light and the East as its superior counterpart-but alters the underlying mimetic premises of its representation. That Tāhir's text makes this move principally by substituting a female European protagonist for the male hero of the classic colonial narrative of exploration and discovery, I suggest, ultimately makes this novel effective at recasting and resisting the epistemological assumptions upon which such narratives were founded, while simultaneously rendering it aesthetically problematic as a work of postcolonial literature.

If juxtaposing the verisimilitude of Camus's Orientalist literary mode in "La femme adultère" against the story's unrealistic portrait of Janine's embodied experiences of Algeria revealed a degree of formal tension in that literary text, then adopting a similar approach to reading Wāhat al-ghurūb exposes an analogous disjuncture between how the text is constructed to rewrite colonial literary tropes, and its use of Catherine's character in

43 See Bill Ashcroft, Gareth Griffiths, and Helen Tiffin, eds., The Empire Writes Back: Theory and Practice in Post-Colonial Literatures (New York: Routledge, 1989).

44 Barbara Harlow, "Sentimental Orientalism: Season of Migration to the North and Othello," in Season of Migration to the North by Tayeb Salih: A Casebook, ed. Mona Takieddine Amyuni (Beirut: American University of Beirut, 1985), 75.

45 Hoda Elsadda, Gender, Nation, and the Arabic Novel: Egypt, 1892-2008 (Syracuse: Syracuse University Press, 2012), 165. 
particular to achieve this end. Like Janine, Catherine is a female figure in a male-authored text who resists being fully instrumentalized to the extradiegetic purposes of the literary narrative within which she exists. Yet Catherine's complexity as a character who grows and changes over the course of Tahir's novel, even if the emancipatory potential of her development remains ultimately unrealized in the novel's final chapters, also invites us to imagine her otherwise than Tāhir himself has: as a woman whose non-normative affective encounters with colonial space render her body transgressive to colonial paradigms and simultaneously to the conventions of colonial literary writing.

To prepare for the perilous trek across 350 miles of Saharan desert that she and Mahmūd will undertake to reach Siwa, Catherine studies voraciously "the books of travelers and historians, and everything I was able to find in the bookshops of Cairo" for information "about the route, and about the wells, dunes, and storms." She believes that these books contain all that there is to know "about the real desert." ${ }^{6}$ A few days into the journey, however, their camel caravan is overtaken by a severe sandstorm for which all of Catherine's book-learning can offer no solutions. Shocked out of the illusion that she can attain intellectual mastery over the desert by her confrontation with the raw physicality of a space that exists neither within books nor as an image "captured in time" by its own historicity, ${ }^{47}$ but instead in the immediate present of her sensual experiences of it, Catherine begins to find the Egyptian landscape sexually arousing. The desert sand, she discovers, emits "an erotic smell [rä'ihah shahwäniyyah] that not only penetrates my nose [tunfidh ilā anfī] but to which all the pores of my body open up." 48 The gently swelling dunes are like "rounded ... small domes or breasts on the chest of the desert [nuhüdfi sadr al-sahrā']," and each time her camel crosses one, her body "throbs ... with the vibration of descending it [yakhfiq ... ma'a ihtizāz al-hubūt ]." 49

Catherine's arousal is capacious and delinked from heterosexual categories of desire; she is as attracted by the desert's breasts as she is by the idea of being penetrated by it. Within the representational formulas of Tâhir's novel, the Egyptian desert-aschronotope functions as what Muhsin Al-Musawi terms a "threshold" or liminal space, "pregnant with crisis, decision, suspense, and ambivalence." In Al-Musawi's list of the conventional chronotopes of the postcolonial Arabic novel-including "a desert, a rocky land, a palace, a dungeon, a house, a staircase, a corridor, a passage, a square and a street"-the desert is unique in being also a topographic feature of the colonial or postcolonial nation, coextensive with at least some portion of this nation's identifiable, bounded surface area. ${ }^{50}$ Despite being therefore subject to the conceptual and pragmatic mechanisms of (post)colonial sovereignty-cartography, infrastructural development, the establishment and preservation of administrative boundaries-the desert is resistant to being fully managed or encompassed by these means. "Unmapped" and unmappable in the discourse of colonial exploration, the desert is where epistemological certainty runs up against the limits of observation and categorization. ${ }^{51}$ For Catherine, her

46 Tāhir, Wāhat al-ghurūb, 56.

47 See Mitchell, Colonising Egypt, 140.

48 Tāhir, Wāhat al-ghurūb, 57.

49 Tāhir, Wāhat al-ghurūb, 59.

50 Muhsin Al-Musawi, The Postcolonial Arabic Novel: Debating Ambivalence (Leiden: Brill, 2003), 4-5.

51 In the account given by the British explorer Wilfred Thesiger of traveling through the Empty Quarter of the Arabian Peninsula in the 1940s, the desert is repeatedly referred to in these terms: "I tried to work out our 
experience in the desert locates her physiologically in her colonial surroundings, so that she begins to perceive them with the same phenomenological thickness that from the very start of Camus's story enriches Janine's perceptions of colonial Algeria and makes her interact with it differently than Marcel does.

Narratively, the episode in the desert redirects Catherine's character toward a different set of outcomes than her earlier portrayal had signaled us to expect for her. She does not find Alexander the Great's tomb at Siwa; instead, she meets Malikah, a young Siwan widow, who, according to tribal dictum, has been ritually proscribed from contact with other members of the community following her husband's death. One day while Mahmūd is away attending to business in the oasis town, Malīkah arrives unannounced at the house where he and Catherine are living and throws herself upon Catherine, kissing her and attempting to pull off her clothing. At being touched like this, Catherine feels a mixture of "revulsion" ("ishmi 'zā z") and "pleasure" ("ladhdhah"), and her body trembles all over with "agitation" ("infi 'al') and "shudders" (" $r i$ 'shah"). ${ }^{52}$ Before their intimate moment can progress further, however, Mạmmūd returns home and, finding Malīkah and Catherine together and believing his wife to be in danger, he fires his gun at Malìkah, who flees.

Reflecting afterward on her encounter with Malīkah, Catherine is unable to reconstruct a coherent account of it:

I try to understand what happened and to evaluate my part in it. Was it she who seduced me? I who seduced her? Was it seduction really [bil-fi l], or was it fear? ... What did she want really [bil-fi $\left.{ }^{\prime}\right]$ ? When she hugged me her embrace was as delicate as a child's. It was I who was overtaken at that moment by the idea of Sappho and her feminine beguilements. Was I under the sway really [bil-fi $\left.{ }^{\prime}\right]$ of the poetess of Lesbos, or did I dread her influence? Did I yearn for it or reject it? ... Why did she kiss my bosom? What exactly happened in that instant? Did her surprise at my bare bosom drive her to kiss it, or was it I who pulled her to me? ...

Assessing my role [in the situation], I concluded in the end that this really [bil-fi $l]$ was not my true self [laysat haquīqatī]..$^{53}$

Catherine tries to justify her physiological response to Malīkah's advances as an effect of her classical education in Ireland, whereby it is the same-sex erotic verses of the seventhcentury BCE Greek poet Sappho-recalled to her mind by Malikah's actions-that have been the cause of her arousal, rather than Malikkah herself. Yet Catherine's body, on which the impress of Malīkah's kiss still lingers, refuses this explanation. What happened "really" ("bil-fi'), and why, eludes Catherine as long as she views the situation rationally. Only when she accepts that her "true self" ("haqiqat $\vec{\imath}$ ") had nothing to do

position on a map which showed Mughshin and Abu Dhabi but nothing else, except from hearsay" (155); "[Across the desert] I could see other and nearer mountains, none of which were marked on my map" (17576); "All this country was completely unmapped, but I was now able to fix its general outlines" (197). See Wilfred Thesiger, Arabian Sands (New York: Penguin Classics, 2007).

52 Tāhir, Wāhat al-ghurūb, 204.

53 Ṭāhir, Wāhat al-ghurūb, 243. 
with what she just experienced via her body can she begin to come to terms with the erotic pleasure that physical contact with Malikah gave her, although she is in a heterosexual marriage to a man. Why, after all, has she always been so drawn to Sappho's poetry? Is it perhaps a woman's touch that she has been waiting for all along to feel sexually fulfilled, after two successive husbands have failed to satiate her erotically? Once Catherine embraces the phenomenological mode of approaching colonial space that the desert taught her, she crosses the threshold toward a new awareness of what her body wants from the material experiences that the colony can provide, which is fundamentally different from what she thought she wanted from it intellectually.

Out of this intimate union between a female European Orientalist and an Amazigh woman arises a potential for a holistic refiguring of the ways that women's bodies generally, and female sexuality specifically, have been troped in both colonial literature about the West-East encounter and in this literature's rewritings from within the colonized and formerly colonized world. As Rana Kabbani notes, Oriental female characters in colonial-era European literature are persistently equated with "the sexual urge itself, unappeasable and intransigent," such that the Western men in these stories are almost invariably unable to avoid being seduced by them even at the cost of abdicating their own moral and civic duties. ${ }^{54}$ Arabic novels from the colonial and immediate postcolonial periods are no less rife with European female characters whose naturalized sexuality emblematizes the West's essential materialism, spiritual depravation, and difference vis-à-vis the East that is personified by these works' Arab male protagonists, as Rasheed El-Enany observes. ${ }^{55}$ Examples include the characters of Susie in Tawfīq al-Hakīm's 'Usfür min al-sharq (Bird from the East, 1938), a French salesgirl who becomes the object of infatuation for a young Egyptian expatriate in Paris, nearly causing his personal and moral ruin; Mary in Yahyā Haqqī's Qindīl Umm Hāshim (The Lamp of Umm Hashim, 1944), the English girlfriend of the novella's Egyptian protagonist during his medical schooling abroad who attempts to lure him away from his spiritual roots with her crass materialism; and Jean Morris in al-Ṭayyib Șālih’s Mawsim al-hijrah ila al-shamāl (Season of Migration to the North, 1966), the Sudanese main character's English wife with whom he has violent sexual intercourse and whom he ultimately kills in an act of symbolic retribution for the violence of British colonialism in the Sudan.

The brief lesbian romance in Wăhat al-ghurūb, by contrast, shows how two female bodies can encounter each other within a literary representation of colonial contact yet outside the heterosexually gendered dramatization of this process that these earlier works of fiction reiterate. The canonical paradigm is invoked in Tāhir's novel only to yield to a West-East encounter at the heart of the narrative that transpires via lateral exchanges of erotic pleasure between bodies whose civilizational ties are absolutely irrelevant to how each body affects and is affected by the other, and whose identical sex makes these bodies moreover resistant to being reduced to symbols of the respective agency or passivity of the two cultures with which they are superficially affiliated.

54 Rana Kabbani, Imperial Fictions: Europe's Myths of Orient (London: Saqi, 2008), 46.

55 See Rasheed El-Enany, Arab Representations of the Occident: East-West Encounters in Arabic Fiction (New York: Routledge, 2006), 42. 
Reina Lewis has proposed that the "differential, gendered access to the positionalities of imperial discourse" that was open to European women during the colonial erawomen who were themselves othered within the hegemonic cultural and discursive frameworks of their Western societies-equipped them to approach "the Orient and the Orientalized 'other' [in ways] that registered difference less pejoratively and less absolutely" relative to how the Orient and its people were typically viewed by male colonialists. ${ }^{56}$ Following from Lewis's observations, Catherine's "gendered" relationship to the Oriental other that Malikkah embodies can be seen as demonstrating a means of accessing the Orient's difference otherwise than through the favored epistemological apparatuses of imperial discourse, and instead through the perceptions and affects of the body. In this regard, Catherine's encounter with Malikah could result not only in "a decolonization of self," per Pratt's reading of the transformative potential of Janine's orgasmic moment at the fort in "La femme adultère," but in a decolonization of the other as well. Just as the phenomenological immediacy of the colonial space of the desert rendered it elusive to being known in advance of Catherine's physical experience of it, the immediacy of how Catherine's body responds to Malikkah's touch affirms Malīkah herself as an inhabitant of this space whose physiological materiality exceeds Orientalist imaginings of the other.

The final third of the novel that follows the scene of the two women's tryst, however, does not bear out the transgressive possibilities that this episode registers. Not only do Catherine and Malīkah never meet again, but Malīkah commits suicide for reasons that are never made fully clear, and Catherine resolves to "forget all of this and put it behind me," in order to "recommence my work and my research ... [and] recover the true Catherine [Käthrīn al-haqiqiyyah]." 57 If Catherine's liaison with Malīkah further perpetuates a shift in her character that was initiated during her journey across the desert, then this moment also marks the limit of how much she can change. Marcia Lynx Qualey, reviewing Wähat al-ghurūb's English translation, observes a "frustrating" lack of believable character development in how the latter part of the book unfolds, illustrated first by Malīkah's enigmatic suicide and subsequently by an underrealized plotline involving Catherine's sister Fiona, who joins Catherine and Mahmūd in Siwa, becomes briefly romantically entangled with Mahmūd, and then dies herself from a mysterious illness. These moments of narrative dissonance are described by Qualey as instances of characters being "moved across the page for the greater explication of theme"; 58 Rachel Aspden observes along similar lines that the novel's characters "behave more like ciphers than real people." 59

Catherine's awakening to an embodied and erotic mode of experiencing colonial space, which leads to no permanent evolution for her character, instead produces a crisis within the formal apparatuses of the novel as a work of postcolonial literature. In AnneMarie McManus's reading of Wăhat al-ghurūb, it is a text that restages the

56 Reina Lewis, Gendering Orientalism: Race, Femininity and Representation (New York: Routledge, 1996), 4

57 Tāhir, Wāhat al-ghurūb, 261.

58 Marcia Lynx Qualey, review of Sunset Oasis by Bahaa Taher, The Quarterly Conversation, December 7, 2009.

59 See Aspden, review of Sunset Oasis by Bahaa Taher, The Guardian. 
epistemological stakes of empire from a postcolonial vantage point, only to reify ultimately a Eurocentric belief in the superiority of reason. This quality of the novel is exemplified for McManus by its portrayal of Malikah as a "subaltern woman," who, oppressed by the primitive superstitions of her tribe yet "external to the march of rational history" whose telos is in the establishment of the postcolonial state, must be sacrificed narratively so that "law and reason" can prevail in the present-day Egyptian national imaginary that Tâhir's work of historical fiction prognosticates. ${ }^{60}$ The female characters in Wăhat al-ghurūb by this account are no more permitted to act upon the affective inclinations of their bodies than the other fictional women who populate a lineage of colonial and postcolonial literary texts. Rather than being used to personify the cultural stakes of the West-East encounter, they are tied here, in McManus's reading, to the drama of national self-determination that the novel enacts. In this respect, Tăhir's novel is consistent with a tradition of Egyptian literary treatments of nationalistic themes since the nineteenth century that employ female characters to symbolize or allegorize various obstacles facing the emergent nation-state. ${ }^{61}$

And yet-and if "in overt tension" with the novel's mimetic aims, as McManus suggests ${ }^{62}$-the bodies of these same female characters in Wăhat al-ghurūb dispute colonial imaginings of how a European self encounters the otherness of the colony. The novel's descriptions of how Catherine experiences first the sensorium of the desert, and then the sensations triggered by Malīkah's touch, register Egypt's materiality via the affective responses that colonial space produces in her body. These responses linger as an aftereffect of Tāhir's act of literary writing, gesturing toward the possibility of a different arc that Catherine's character might have taken, perhaps even one consonant with the novel's decolonial commitments. Wähat al-ghurūb concludes with Mahmūd's exhortations to his fellow Egyptians to fight for a future free of colonial rule as he lies dying beneath the literal rubble of the country's glorious past, having dynamited one of Siwa's ancient temples to perform symbolically the futility of seeking a source of self-realization in Egyptian history. If his hopes for a postcolonial nation die with him, however, then the decolonization of Egypt has already been set in motion within the diegetic reality of the novel by what Catherine has experienced in the desert and at the oasis-albeit ambivalently, for her decolonizing potential comes from her body, and it is thus unassimilable to the literary aesthetic function to which her character has been assigned.

\section{Fictional Bodies}

For Wen-chin Ouyang, Wāhat al-ghurūb exemplifies a broader tendency in postcolonial Arabic literature to yoke nationalist politics to literary form-in this case, by using the vehicle of historical fiction to "argue ... with both the past and the West" while simultaneously testing the "authenticity and originality of the Arabic novel" against its Western precursors. This trend is one that, according to Ouyang, has to some extent

60 Anne-Marie E. McManus, "Scale in the Balance: Reading with the International Prize for Arabic Fiction ('The Arabic Booker')," International Journal of Middle East Studies 48 (2016): 232.

61 See Beth Baron, Egypt as a Woman: Nationalism, Gender, and Politics (Berkeley and Los Angeles: University of California Press, 2005).

62 See McManus, "Scale in the Balance," 233. 
restricted other modalities of writing from achieving prominence in the modern Arabic literary field, and it has particularly disadvantaged "women writers," who "understandably take exception to the kind of unabashed misogyny exhibited in the story of the [Arabic] novel's love affair with the nation-state." For these reasons, Ouyang argues, the "dominance of the nation-state as the structuring episteme and chronotope" of postcolonial Arabic fiction is "problematical" both "politically and aesthetically." 63

Bearing in mind Ouyang's critique, this article has argued that what is a problem for postcolonial Arabic literature in general provides in Wāhat al-ghurūb, however, an opportunity for reading this novel against the grain of its apparent political and aesthetic commitments, including as they have been described by Tāhir himself. ${ }^{64}$ With respect to how Wăhat al-ghurūb fits into a tradition of twentieth- and twenty-first-century Arabic fiction that addresses the dynamics of Western colonialism in the Arab Middle East, I would like to suggest in closing that recovering a role for Catherine's character other than that seemingly intended for her by the author enables us to identify Wăhat al-ghurū $b$ with a different transgressive potential and a different set of recalcitrant aesthetic possibilities than those typically accorded to the postcolonial Arabic novel. The novel's erotic phenomenology of Egyptian space as it is experienced by a female body poses a challenge both to the colonial literary discourse that the text is configured to "write back" against and to the literary dramatization of the emergence of a rational Egyptian nation-state that it offers instead. This, too, is an aesthetic effect produced by Țâhir's novel, and it affirms the irreducibility of this body and of female sexual experience to such instrumental representations.

Only by framing my reading of Tāhir's novel in the second half of this article vis-à-vis my earlier reading of Camus's story could these contradictory implications of Tāhir's gender-flipping postcolonial rewriting of the colonial literary script of Orient-aswoman be elucidated. As Camus's story reveals, an aesthetic strategy that yokes representations of female erotic affect to any kind of colonial politics, whether in support of the epistemologies of empire or against them, proves unsustainable. Elizabeth Grosz argues, drawing on the work of the French feminist thinker Luce Irigaray, that the inherent leakiness of the female body guarantees its "cultural unrepresentability ... within prevailing philosophical models of ontology"-and, we might add, within prevailing literary models of the same ${ }^{65}$ For Tarek El-Ariss, the leaking body is identified with a critique of power made possible by this body's affective autonomy from all epistemological structures, especially those that seek to relegate embodiment to a discursive or mimetic given. Subverting such structures through its refusal or incapacity to conform to them, the leaking body activates fiction as the site and medium of its interventions, "touching bodies and altering narrative course, subverting power

63 Wen-chin Ouyang, Politics of Nostalgia in the Arabic Novel: Nation-State, Modernity and Tradition (Edinburgh: Edinburgh University Press, 2013), 225-26.

64 Ṭăhir has stated that his primary aim in writing Wāhat al-ghurūb was to use a fictional reimagining of an era in Egypt's colonial history to critique by analogy the neocolonialism of contemporary twenty-firstcentury Western approaches to the Middle East: "I wanted to deal with western domination in our part of the world. ... I was very much dismayed by the recent occupation of Iraq. We have gone back to classical colonialism, and that made me want to look back at the history of Egypt under occupation." See Mona Anis, "The Unbearable Weight of History," Al-Ahram Weekly, February 7-13, 2008.

65 Grosz, Volatile Bodies, 195. 
relations and the codes regulating gender, the sacred and the profane, the private and the public, and the knowable and the unknowable." 66

Embracing the fictionality of the female protagonists in these two works of literature invites us to contemplate a range of possibilities for each character beyond the official closure of the narrative. What if Janine, instead of returning to Marcel at the hotel, were truly to become the "adulterous wife" promised by the story's title: were to seek out sexual satisfaction with the French legionnaire from the bus or the Algerian man in the town, with anyone but the plodding, unattractive husband with which Camus's own imagination has saddled her? What if Catherine, instead of reverting to being the stereotypically Orientalist European wife of the tormented Egyptian "mimic man" that Mahmūd epitomizes in his struggle toward self-realization as an enlightened postcolonial subject, ${ }^{67}$ were to escape with Malikkah into the desert-thereby saving both the Siwan woman and herself not by acting rationally, but by giving in to the bilateral impulses of their desiring bodies?

Literary characters, freed from the tropic structures in which they are contained, drift in alternative narrative directions and enter into alternative aesthetic configurations. Yielding fully to the erotic inclinations of their bodies, these two European women would conjure colonial space aesthetically, within the diegetic reality of a literary text, as no longer colonial but as the extensive whole of "the world that takes shape around" them: as the totality of the phenomenal environment in which the experiences of embodied life unfold. ${ }^{68}$ Out of the literary conjunction of a female character with the land of the (post)colonial nation, what would emerge would be not a drama of self and other but a fiction of bodies that are "always becoming otherwise, however subtly, than what ... [they] already" are, decomposed and recomposed perpetually by "the forces of encounter" that act on them. ${ }^{69}$

To draw such conclusions about these two works of literature that inscribe the dynamics of the colonial encounter onto the female body is to propose ultimately neither a strictly decolonial nor feminist reading of them. Instead, what might be gained by the approach followed in this article, I suggest, is something closer to an ethical means of reexamining the mimetic conventions that colonialism spawned in multiple intersecting traditions of literary writing, in order to locate sites and modes of resistance in fiction that lie outside the binaries of colonizer/colonized and male/female that have historically provided the aesthetic coordinates for such writing. Literary representations of nonnormative bodies bear a potential to "return the aesthetic domain to an active ethical core," insofar as such representations hold within them the threads of their own unraveling. ${ }^{70}$ The fictional body, irreducibly affected by its encounters with the world, refuses to be merely a trope, a symbol, or an occasion for colonial politics.

66 Tarek El-Ariss, Leaks, Hacks, and Scandals: Arab Culture in the Digital Age (Princeton: Princeton University Press, 2019), 34.

67 In this regard, Mahmūd's character is recognizable as a literary version of the quintessential colonized subject whose psychological predicament is described by Homi Bhabha in "Of Mimicry and Man: The Ambivalence of Colonial Discourse," October 28 (1984): 128.

68 See Sara Ahmed, "Happy Objects," in The Affect Theory Reader, eds. Melissa Gregg and Gregory Seigworth (Durham, NC: Duke University Press, 2010), 32.

69 See Gregory Seigworth and Melissa Gregg, "An Inventory of Shimmers," in The Affect Theory Reader, eds. Melissa Gregg and Gregory J. Seigworth (Durham, NC: Duke University Press, 2010), 3.

70 Quayson, Aesthetic Nervousness, 19. 